\title{
Nitrobenzene biodegradation ability of microbial communities in water and sediments along the Songhua River after a nitrobenzene pollution event
}

\author{
LI Zonglai, YANG Min*, LI Dong, QI Rong, LIU Huijuan, SUN Jingfang, QU Jiuhui \\ State Key Laboratory of Aquatic Chemistry, Research Center for Eco-Environmental Sciences, Chinese Academy of Sciences, \\ Beijing 100085, China.E-mail: yangmin@rcees.ac.cn
}

Received 26 February 2008; Revised 10 April 2008; accepted 30 April 2008

\begin{abstract}
More than $100 \mathrm{t}$ of nitrobenzene (NB) and related compounds were discharged into the Songhua River, the fourth longest river in China, because of the world-shaking explosion of an aniline production factory located in Jilin City on November 13, 2005. As one of the efforts to predict the fate of residual NB in the river, NB biodegradation abilities by microbes in the water and sediments from different river sections were evaluated systematically. The results indicated that microbial communities from any section of the river, including one section at the upper stream of the NB discharging point, had the ability to biodegrade NB under aerobic (for river water samples) conditions at $22 \pm 1^{\circ} \mathrm{C}$ or anaerobic (for sediment samples) conditions at $10 \pm 1{ }^{\circ} \mathrm{C}$. $\mathrm{NB}$ degradation rates of microbial communities in the downstream sites were markedly higher than those in the upstream site, indicating that NB degradation abilities were enhanced because of the pollution of NB. Aerobic degradation got neglected at a temperature of $10^{\circ} \mathrm{C}$ or lower. The production of nitrosobenzene and aniline during aerobic biodegradation suggested the existence of at least two different NB degradation pathways, and the occurrence of the catechol-2,3-dioxygenase (C23O) gene and the significant decrease of dissolved organic carbon (DOC) indicated that NB could be mineralized under aerobic conditions. Although it was a fact that the river have frozen-up during the NB accident, it was speculated that biodegradation was not the major process responsible for the decrease of NB flux in the river.
\end{abstract}

Key words: nitrobenzene; the Songhua River; pollution accident; biodegradation; low temperature

\section{Introduction}

The Songhua River, with a full length of about 1,840 $\mathrm{km}$, flows through Jilin and Heilongjiang Provinces into the Amur River, as the main tributary, before entering into Russia. As the fourth longest river in China, the Songhua River is the main source of water for the cities and villages in the region. An explosion occurred on 13 November 2005, at an aniline production factory of the Jilin Petrochemical Corporation, Jilin Province, China, which led to the world-shaking water pollution accident, in which over $100 \mathrm{t}$ of $\mathrm{NB}$ and related compounds were released into the Songhua River (UNEP, 2005). This event forced Harbin City, which is located $200 \mathrm{~km}$ downstream from the NB discharging site and has four million inhabitants, to stop water supply for four days. For controlling the losses and impact of the accident at a level as low as possible, the government started a wide range of investigations to understand the behavior and fate of residual NB in the river. Evaluation of NB degradation abilities of microbes at different river sections was one of the main tasks of the investigation (Liu et al., 2008; Wang et al., 2008).

Previous studies indicated that NB could be degraded by many kinds of microorganisms from active sludge

\footnotetext{
* Corresponding author. E-mail: yangmin@ @rcees.ac.cn.
}

(Majumder and Gupta, 2003; Zhao and Ward, 1999) and contaminated water or soils (Nishino and Spain, 1993; Spain, 1995; Ye et al., 2004). At least three different NB biodegradation pathways (two aerobic and one anaerobic) have been reported (Hugh, 2005): (1) formation of catechol with the catalysis of NB 1,2-dioxygenase (He and Spain, 1999; Nishino and Spain, 1995); (2) formation of catechol via oxidation of aniline, with the catalysis of aniline dioxygenase (Liu et al., 2002); and (3) reduction of NB with the catalysis of NB nitroreductase directly (He and Spain, 1999). Catechol could be further degraded to 2-hydroxymuconic semialdehyde and cis,cis-Muconate, respectively (He and Spain, 1999), with the catalysis of catechol-2,3-dioxygenase ( $\mathrm{C23O}$ ) or catechol-1,2-dioxygenase $(\mathrm{C} 12 \mathrm{O})$. The nitro group is a strong electron-withdrawing group, which causes the NB biodegradation under anaerobic conditions to become more rapid than that under aerobic conditions, and normally the reductive reaction happens first under natural conditions (Gurevich et al., 1993).

The reported half lives of NB in the environment varied largely, ranging from 2 to more than $625 \mathrm{~d}$, which makes it difficult to evaluate the fate of NB in the environment. Yuan and Lang (1991) found that NB biodegradation rates in the Songhua River water depended mainly on the temperature 
and acclimating conditions in a study on biodegradation kinetics of NB.

On the basis of these results, the NB biodegradation abilities of microorganisms in water and sediments from different sites of the Songhua River were evaluated under both anaerobic and aerobic conditions at different temperatures in this study. Moreover, the possible biodegradation pathways were examined by combining degradation intermediate analysis using gas chromatography/mass spectrometry (GC/MS) and polymerase chain reaction (PCR) of the related degradation genes. The results in this study were very important for the evaluation of NB fate in the river after the explosion.

\section{Materials and methods}

\subsection{Sample collection}

Seven sampling sites, including one upper stream site (A), one in the wastewater discharging channel (B), through which the NB containing wastewater flowed during the accident, and five downstream ones, along the Songhua River were selected for this study (Fig.1 and Table 1). Sampling sites A-D are located in Jilin Province and $\mathrm{E}-\mathrm{F}$ are located in Heilongjiang Province. Water samples were taken from the surface layer, and stored in hexafluoropropylene bottles at $4^{\circ} \mathrm{C}$. For the sections covered with ice, water samples were taken from the holes after the ice layer was broken with an icebreaker. Sediment samples were collected in a grab bucket sampler and stored in stainless iron boxes at $4^{\circ} \mathrm{C}$.

\subsection{Pretreatment methods}

Water samples were filtrated using GF/C glass fiber membranes (47 mm, Whatman, England). Samples of high

Table 1 Selected sampling site information of Songhua River

\begin{tabular}{llllll}
\hline $\begin{array}{l}\text { Sampling } \\
\text { site }\end{array}$ & Code & $\begin{array}{l}\text { Longitude } \\
\left({ }^{\circ} \mathrm{E}\right)\end{array}$ & $\begin{array}{l}\text { Latitude } \\
\left({ }^{\circ} \mathrm{N}\right)\end{array}$ & $\begin{array}{l}\text { Distance } \\
(\mathrm{km})\end{array}$ & Description \\
\hline Fengman & $\mathrm{A}$ & 126.67 & 43.72 & $\approx 30$ & Reference \\
Shihaoxian & $\mathrm{B}$ & 126.50 & 43.91 & 0 & Explosion site \\
Jiuzhan & $\mathrm{C}$ & 126.47 & 43.94 & 9 & Downstream \\
Sanjiangkou & $\mathrm{D}$ & 124.93 & 45.53 & 388 & Downstream \\
Hulanhekou & $\mathrm{E}$ & 126.84 & 45.95 & 588 & Downstream \\
Jiamusi & $\mathrm{F}$ & 130.23 & 46.81 & 1,018 & Downstream \\
Tongjiang & $\mathrm{G}$ & 132.46 & 47.64 & 1,262 & Downstream \\
\hline
\end{tabular}

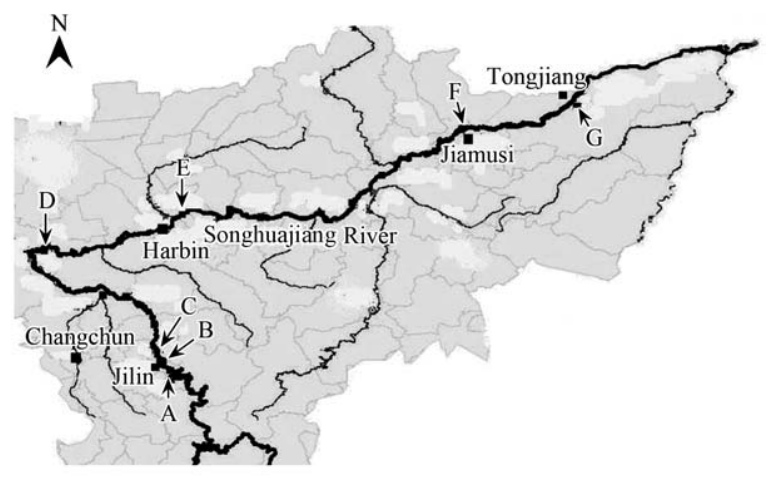

Fig. 1 Schematic map of sampling sites.
NB concentrations were directly analyzed using HPLC, whereas, those of low concentrations were analyzed after concentration with solid-phase extraction (SPE) (Dias and Poole, 2002). In brief, water was passed through an Oasis ${ }^{\circledR}$ HLB cartridge $(200 \mathrm{mg}, 6 \mathrm{ml}$ barrel, Waters, America), which was activated successively by $10 \mathrm{ml}$ dichloromethane, $10 \mathrm{ml}$ acetic ether (HPLC grade, Fisher, America), and $10 \mathrm{ml}$ pure water. The cartridges were eluted successively by $10 \mathrm{ml}$ dichloromethane, $10 \mathrm{ml}$ acetic ether, and $10 \mathrm{ml}$ mixture (ether dichloromethane $5 \mathrm{ml}$ and acetic $5 \mathrm{ml}$ ). The eluent was dried to $1 \mathrm{ml}$ by blowing nitrogen gas gently and it was filtrated with a $0.45-\mu \mathrm{m}$ pore nylon filter for GC/MS analysis.

Sediment samples were put in $22 \mathrm{ml}$ glass bottles, followed by centrifugation at $5,000 \mathrm{r} / \mathrm{min}$ and $4{ }^{\circ} \mathrm{C}$ for 10 min. After the supernatant was decanted carefully, $10 \mathrm{ml}$ acetonitrile (HPLC grade, Fisher, America) was added, and ultrasonic extraction was performed for $10 \mathrm{~min}$ with the ultrasonic cell crusher $(20 \mathrm{kHz}, 600 \mathrm{~W}$, Scientz-II, Ningbo, China). Following centrifugation, the supernatant was filtrated with a $0.45-\mu \mathrm{m}$ pore nylon filter, for HPLC analysis.

\subsection{HPLC measurement}

NB was detected according to the EPA Method 8330 (EPA, 1994) on a Waters Alliance 2695 separation module, equipped with a Waters 2996A photodiode array detector and a Waters XTerra ${ }^{\circledR}$ MS C18 reversed-phase column ( $250 \mathrm{~mm} \times 4.6 \mathrm{~mm}$ i.d., $5 \mu \mathrm{m}$ particle sizes). The mobile phase was a mixture of water, acetonitrile, and acetic acid $(59.7 \%: 40 \%: 0.3 \%)$, delivered by a pump at a flow rate of $1.00 \mathrm{ml} / \mathrm{min}$. The column was held at $25^{\circ} \mathrm{C}$ and detection was performed at $263.3 \mathrm{~nm}$.

\subsection{GC-MS measurement}

For identification of possible intermediary products, GC-MS analysis was performed using an Agilent $6890 / 5973 \mathrm{GC} / \mathrm{MSD}$ equipped with a $30 \mathrm{~m} \times 0.25 \mathrm{~mm}$ i.d. DB-5 MS column (J \& W Scientific, USA) after SPE concentration of biodegradation samples. The GC oven temperature was programmed from $40^{\circ} \mathrm{C}(3 \mathrm{~min})$ to $300^{\circ} \mathrm{C}(1 \mathrm{~min})$ at $10^{\circ} \mathrm{C} / \mathrm{min}$. The detector and injector temperatures were 300 and $100^{\circ} \mathrm{C}$, respectively. Helium was used as the carrier gas with a flow rate of 1.0 $\mathrm{ml} / \mathrm{min}$. The MS was operated in full-scan mode under the following conditions: ion source (EI) $70 \mathrm{eV}$; interface temperature $250^{\circ} \mathrm{C}$; ion source temperature $220^{\circ} \mathrm{C}$; scan range $(\mathrm{m} / \mathrm{z})$ 46-200.

\subsection{DNA extraction and PCR}

Biomass collected on a $\mathrm{GF} / \mathrm{C}$ filter membrane was washed off with a PBS buffer, and then centrifuged at $8,000 \mathrm{r} / \mathrm{min}$ for $10 \mathrm{~min}$ in a $2-\mathrm{ml}$ centrifuge tube at $4^{\circ} \mathrm{C}$. DNA extraction was according to the phenol-chloroform protocol. PCR reactions (iCycler Thermal Cycler, Biorad, America) were performed with the $C 23 O$ gene (C23OfAAG AGG CAT GGG GGC GCA CCG GTT CGA TCA, C23Or- CCA GCA AAC ACC TCG TTG CGG TTG CC) and $C 12 O$ gene (C12Of- GAA GGA CCG CTA TAT GTT 
GCA GGT GC, $\mathrm{C} 12 \mathrm{Or}$ - TAG TGA ATA TGC GCA GGG CG) specific primers, respectively (Sei et al., 1999).

The programs of PCR were carried out as follows: first denaturation was carried out at $94^{\circ} \mathrm{C}$ for $4 \mathrm{~min}$, and then 40 cycles were completed with denaturation at $94^{\circ} \mathrm{C}$ for $40 \mathrm{~s}$. Annealing was performed at $60^{\circ} \mathrm{C}$. Elongation was conducted at $72^{\circ} \mathrm{C}$ for $40 \mathrm{~s}$ and a final elongation occurred at $72^{\circ} \mathrm{C}$ for $10 \mathrm{~min}$. The PCR products were checked by $1.2 \%$ agarose electrophoresis with the 100 bp ladder marker.

\section{Experiments}

\subsection{Evaluation of NB degradation abilities of microbial communities}

The density of microbes in sediments was estimated using the DAPI (4'-6'-diamidino-2-phenylindole) staining method (Schallenberg et al., 1989). Five grams of sediment samples were washed with $50 \mathrm{ml}$ PBS buffer, and the resulting mixture was filtrated with a sieve net of 100 mesh size to remove coarse particles. Following DAPI staining, microscopic inspection was conducted for 10 fields of vision for each sample to give the cell counts. The results showed that the ratio of microbial cells in the sediments from A to D was approximately 1:4:4:2 .

The biodegradation ability was assessed by the OECD method 302B (1992). The sterile mineral media 150 $\mathrm{ml}$ (with $\mathrm{KH}_{2} \mathrm{PO}_{4} \quad 85 \mathrm{mg} / \mathrm{L}, \mathrm{K}_{2} \mathrm{HPO}_{4} 217.5 \mathrm{mg} / \mathrm{L}$, $\mathrm{Na}_{2} \mathrm{HPO}_{4} \cdot 2 \mathrm{H}_{2} \mathrm{O} 334 \mathrm{mg} / \mathrm{L}, \mathrm{NH}_{4} \mathrm{Cl} 5 \mathrm{mg} / \mathrm{L}, \mathrm{CaCl}_{2} 27.5$ $\mathrm{mg} / \mathrm{L}, \mathrm{MgSO}_{4} \cdot 7 \mathrm{H}_{2} \mathrm{O} 22.5 \mathrm{mg} / \mathrm{L}, \mathrm{FeCl}_{3} \cdot 6 \mathrm{H}_{2} \mathrm{O} 0.25 \mathrm{mg} / \mathrm{L}$, adjusted $\mathrm{pH}$ to 7.4 ) containing $11 \mathrm{mg} / \mathrm{L} \mathrm{NB}$ were added into a series of $250 \mathrm{ml}$ glass flasks. The river water 5 $\mathrm{L}$ or 2.5-10 g wet sediment (according to the microbial densities in the sediments) was used for inoculation. For each sample, the tests were performed with two parallel flasks, one blank flask that contained sterilized river water or sediment together with mineral medium. The flasks were covered with ventilate membranes (hole aperture 0.2 $\mu \mathrm{m}$ ), and incubated in an orbit shaker (HZQ-C, Harbin, China) at $150 \mathrm{r} / \mathrm{min}$ and $22 \pm 1{ }^{\circ} \mathrm{C}$. A 5 -ml sample was taken at a given time interval to determine residual NB concentrations.

\subsection{Biodegradation of NB under low temperatures}

Similar systems were used for the experiments except that the initial NB concentration was about $600 \mu \mathrm{g} / \mathrm{L}$, the rotation speed was $60 \mathrm{r} / \mathrm{min}$, and the temperatures were $0 \pm 1^{\circ} \mathrm{C}$ and $10 \pm 1^{\circ} \mathrm{C}$. The low rotation speed was adopted to suppress the loss of NB through volatilization. Three parallel flasks and one blank flask, which was sterilized with $0.5 \% \mathrm{HgCl}_{2}(W / W)$, were used for each condition.

For the sediment samples, $4 \mathrm{~g}$ sediment samples in dry weight were added into a series of $22 \mathrm{ml}$ airtight glass bottles that were sealed with a Teflon-Silica gel stopper, covered with parafilm (Pechiney, America), after they were filled with river water from the same site. Before $0.10 \mathrm{mg} \mathrm{NB}$ was added, the bottles were incubated at $25^{\circ} \mathrm{C}$ for $3 \mathrm{~d}$, to recover the microbial activities. For each condition, two parallel bottles and one blank bottle were sterilized with $1 \% \mathrm{HgCl}_{2}(W / W)$, and were set up into a double layer airtight plastic bag with one anaerobic package (AnaeroPack, Mitsubishi Gas Chemical Co., Japan), which was incubated at $10^{\circ} \mathrm{C}$, without shaking. At a given time interval, the bottles were taken out to determine the residual NB concentrations in water and sediment systems.

\subsection{Verification of NB biodegradation}

Six flasks $(250 \mathrm{ml})$, each containing $150 \mathrm{ml}$ mineral medium and $15 \mathrm{mg} / \mathrm{L} \mathrm{NB}$, were inoculated with $5 \mathrm{ml}$ microbe containing PBS buffer, which was prepared by washing $20 \mathrm{~g}$ (wet weight) sediment $\mathrm{C}$, using $200 \mathrm{ml}$ PBS buffer, and then shaken at $25^{\circ} \mathrm{C}$ and $150 \mathrm{r} / \mathrm{min}$. For a given period, one flask would be taken out for sampling. The mixture was filtrated with a GF/C glass fiber filter. The filtrate was concentrated by SPE for the analysis of biodegradation intermediates using GC/MS, and the residues on the filter were washed out with PBS buffer for the detection of functional genes using PCR after DNA extraction.

For checking the changes in the dissolved organic carbon (DOC), two big flasks, each containing $1 \mathrm{~L}$ mineral medium and $15 \mathrm{mg} / \mathrm{L} \mathrm{NB}$, were inoculated with $0.5 \mathrm{ml}$ of the microbe containing PBS buffer described earlier (a very small amount of PBS was used to control the background DOC value at a low level). The flasks were sealed and samples were taken at a given time interval, and filtrated with $\mathrm{GF} / \mathrm{C}$ glass fiber membrane for the analysis of DOC on a TOC analysis equipment (Sievers 900, America).

\section{Results and discussion}

\subsection{Evaluation of NB degradation abilities of microbial communities}

The biodegradation abilities of microbes from different sites were compared at $22^{\circ} \mathrm{C}$ using river water and sediment samples as inoculates, respectively, and the results are shown in Figs.2 and 3. NB in the blanks decreased for the duration of the test because of the effects of volatilization.

It was clear that NB in the degradation systems decreased at the begining, suggesting that acclimation time was required for both the river water and sediment systems. Acclimation time varied from 2 to $4 \mathrm{~d}$ for the river water systems, and from 1 to $2 \mathrm{~d}$ for the sediment systems. Subsequently, the NB decreasing rates in the degradation systems became much more rapid than those in the blanks, indicating the occurrence of $\mathrm{NB}$ biodegradation. A rough estimation of NB biodegradation rates was conducted by focusing on the fast decreasing phases, during the experiment, and the results showed that the NB degradation rates of river water were: sites $\mathrm{B}(0.154 \mathrm{mg} /(\mathrm{L} \cdot \mathrm{h}))>$ C $(0.073 \mathrm{mg} /(\mathrm{L} \cdot \mathrm{h}))>\mathrm{D}(0.071 \mathrm{mg} /(\mathrm{L} \cdot \mathrm{h}))>\mathrm{A}(0.052$ $\mathrm{mg} /(\mathrm{L} \cdot \mathrm{h}))$, and those of the sediment were: sites $\mathrm{C}(0.101$ $\mathrm{mg} /(\mathrm{L} \cdot \mathrm{h}))>\mathrm{B}(0.083 \mathrm{mg} /(\mathrm{L} \cdot \mathrm{h}))>\mathrm{D}(0.057 \mathrm{mg} /(\mathrm{L} \cdot \mathrm{h}))>$ A $(0.050 \mathrm{mg} /(\mathrm{L} \cdot \mathrm{h}))$. Microbes in $\mathrm{B}$ and $\mathrm{C}$ sites showed higher NB degradation rates. The sites were exposed to 

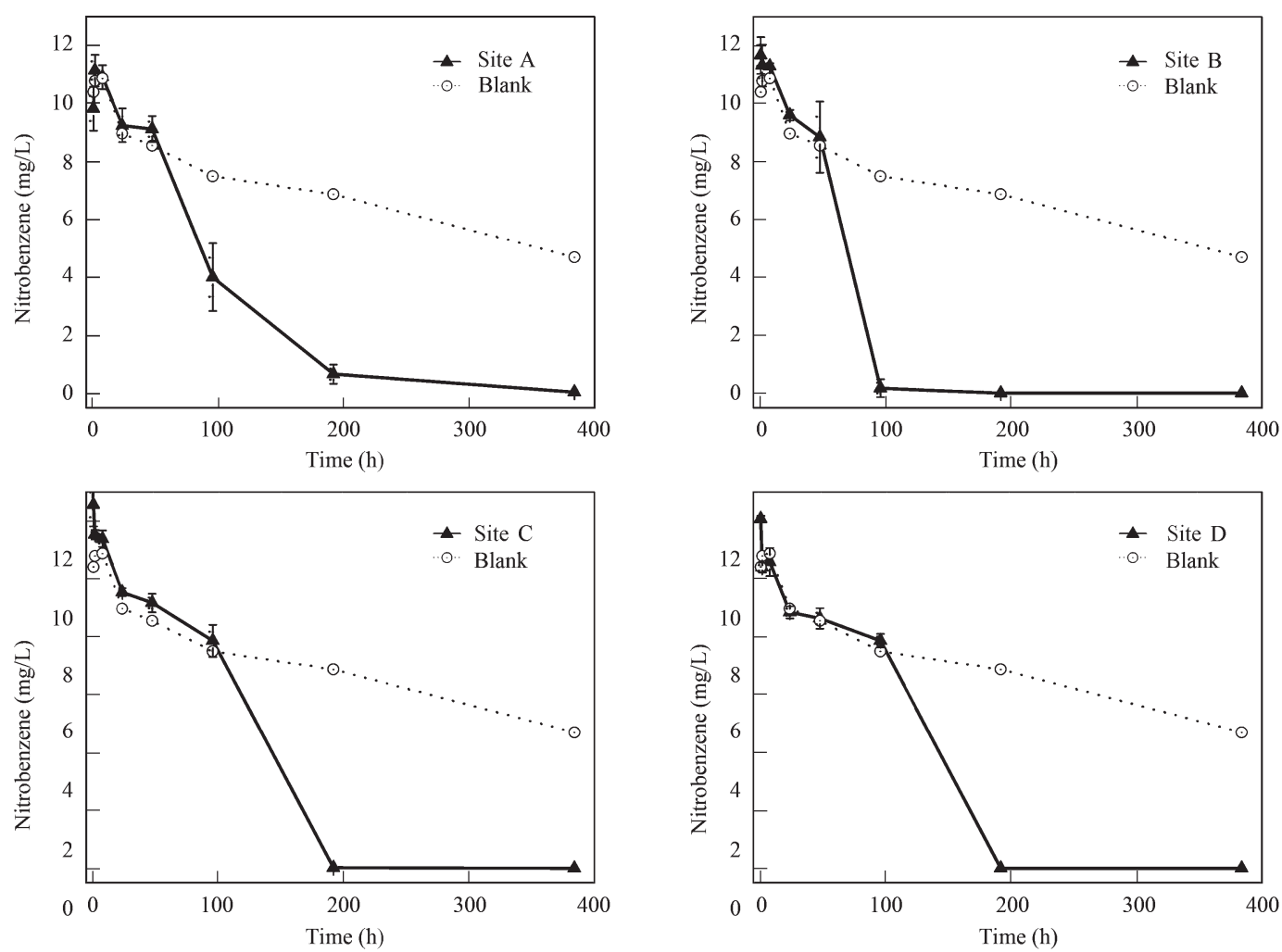

Fig. 2 NB biodegradation abilities of microbial communities in river water from different sites.
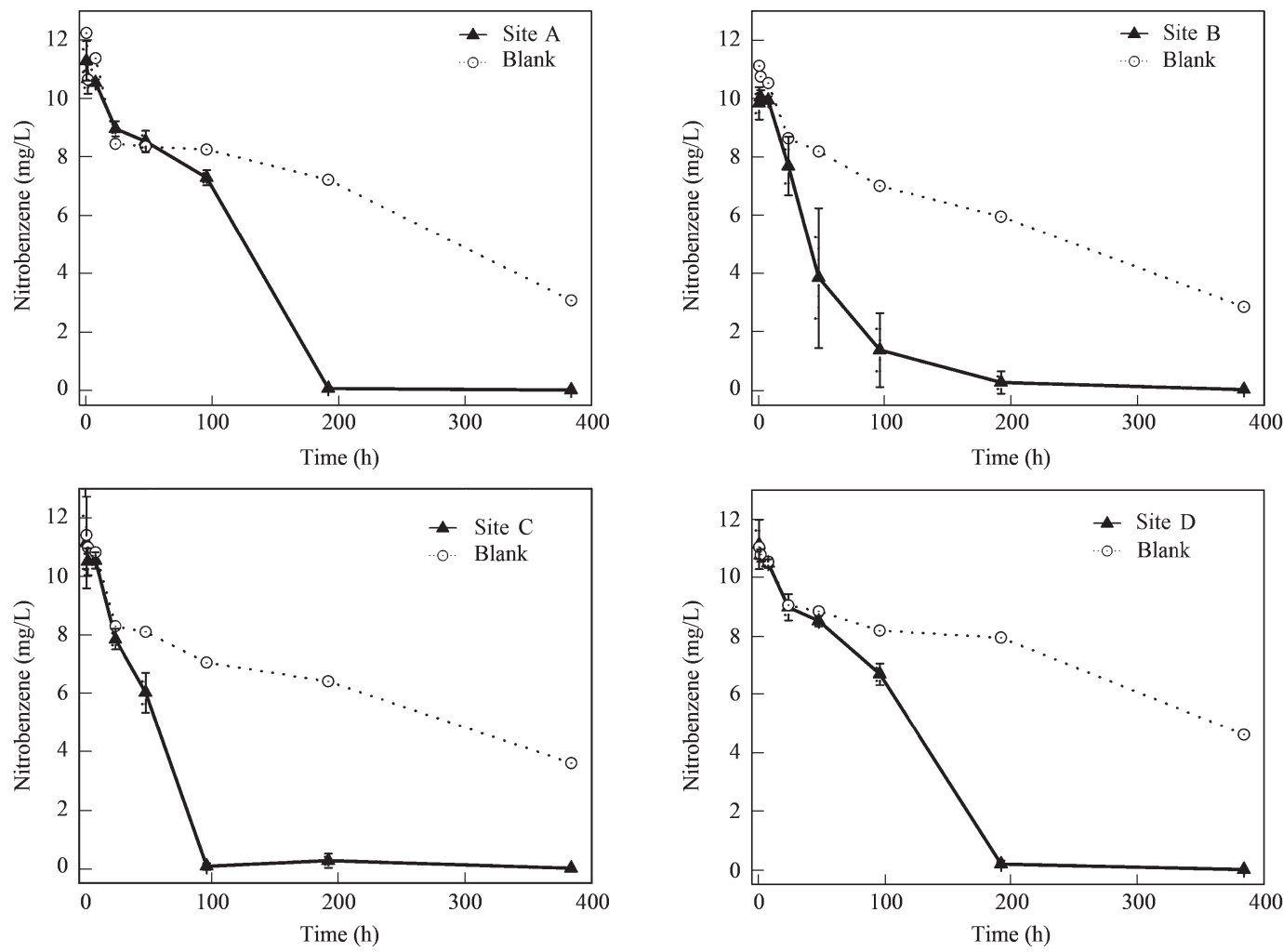

Fig. 3 NB biodegradation abilities of microbial communities in sediments from different sites.

the highest concentration of $\mathrm{NB}$, and still contained NB during the sampling time $(\mathrm{B}, 6.7 \mu \mathrm{g} / \mathrm{L}$ in water and 17.4 $\mathrm{mg} / \mathrm{kg}$ in sediment; C, $0.4 \mu \mathrm{g} / \mathrm{L}$ in water and $1.29 \mathrm{mg} / \mathrm{kg}$ in sediment). Bacterial community clustering based on
DGGE analysis and cloning results demonstrated that the community patterns of sites $\mathrm{B}$ and $\mathrm{C}$ were closely related, and were distinctly different from that of site $\mathrm{A}$ (Li et al., in press). Thus, it was clear that the microbial communities in 
Sites B, C, and D were affected greatly by the discharge of NB. This could explain the differences of NB degradation rates between those sites. It was interesting, however, that even microbes in site A, which were not polluted by NB, demonstrated a relatively high NB degradation rate. This result meant that microbes in the environment generally possessed NB degradation abilities.

\subsection{Biodegradation of NB at low temperatures}

The aerobic biodegradation test results at 0 and $10^{\circ} \mathrm{C}$ are shown in Figs. 4 and 5. The decreasing blank curves at 0 and $10^{\circ} \mathrm{C}$ clearly demonstrate that volatilization of $\mathrm{NB}$ occurs even at a very low temperature. For the tests at $0^{\circ} \mathrm{C}$, the degradation curves and the blank curves overlap each other, indicating that no perceptible biodegradation occurs at this temperature. For the tests at $10^{\circ} \mathrm{C}$, the degradation curves and the blank curves do not overlap, but they are almost parallel for the experimental duration (15 d), except for one system using site $\mathrm{D}$ water. In comparison with the other system, this system is characterized by the formation of unidentified flocs, which might be responsible for the decrease of NB through adsorption. Therefore, it is considered that biodegradation of NB at this temperature does not occur substantially either. These results demonstrate that aerobic biodegradation of $\mathrm{NB}$ at low temperatures is not favorable.

The results of anaerobic NB biodegradation in sediments at $10^{\circ} \mathrm{C}$ are shown in Fig.6. NB in the blanks did not decrease because of the use of airtight bottles. NB in all the biodegradation systems demonstrated a clear decreasing trend, suggesting that anaerobic degradation was possible at this temperature. It was proved that anaerobic NB biodegradation was normally easier than aerobic biodegradation (Razo-Flores et al., 1999; Spain, 1995; Ye et al., 2004). Except for sediment from site A, all sediments could completely remove NB within $8 \mathrm{~d}$. In comparison, the sediment from A showed a markedly low NB degradation rate.
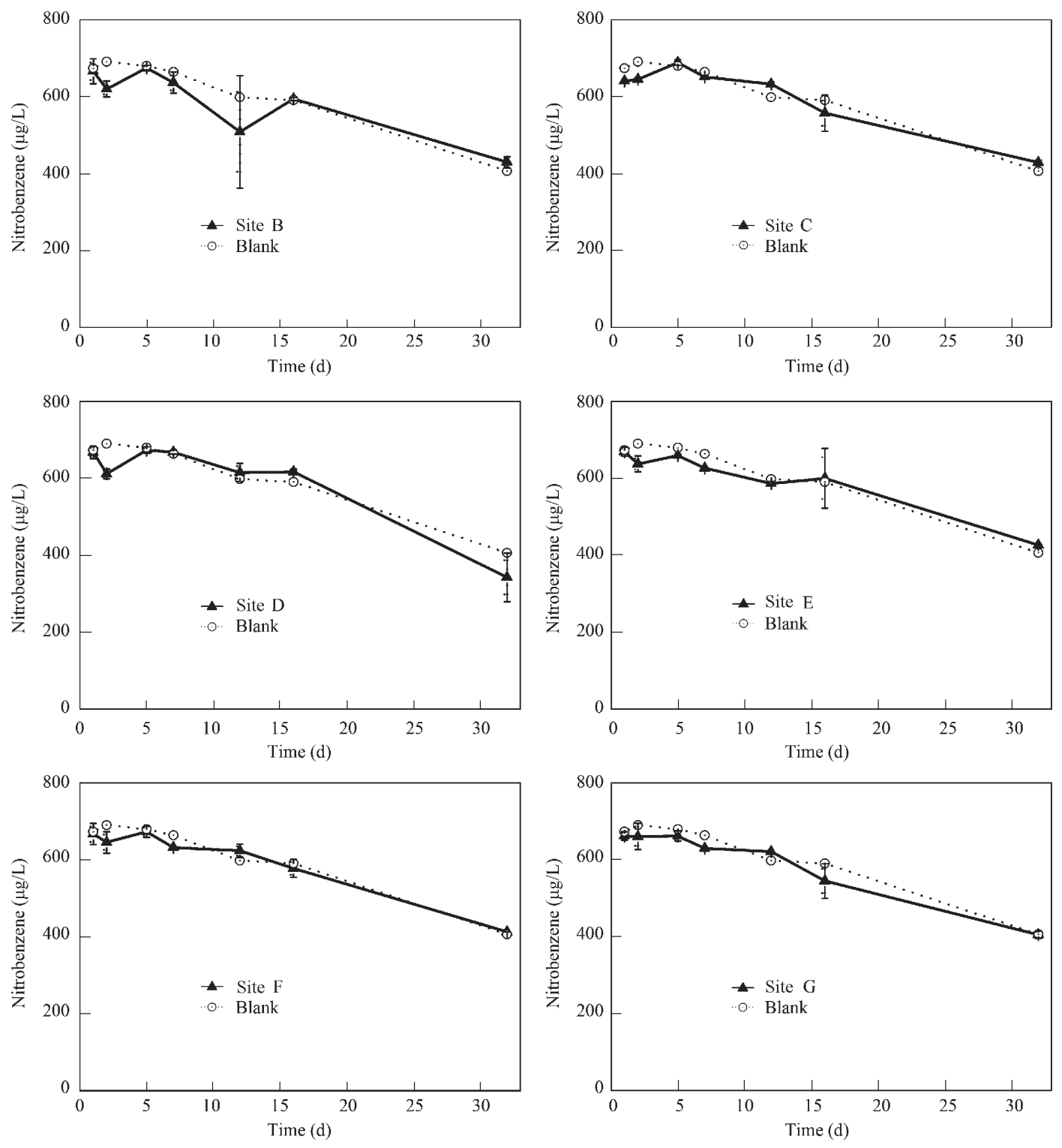

Fig. 4 NB biodegradation in river water at $0^{\circ} \mathrm{C}$. 

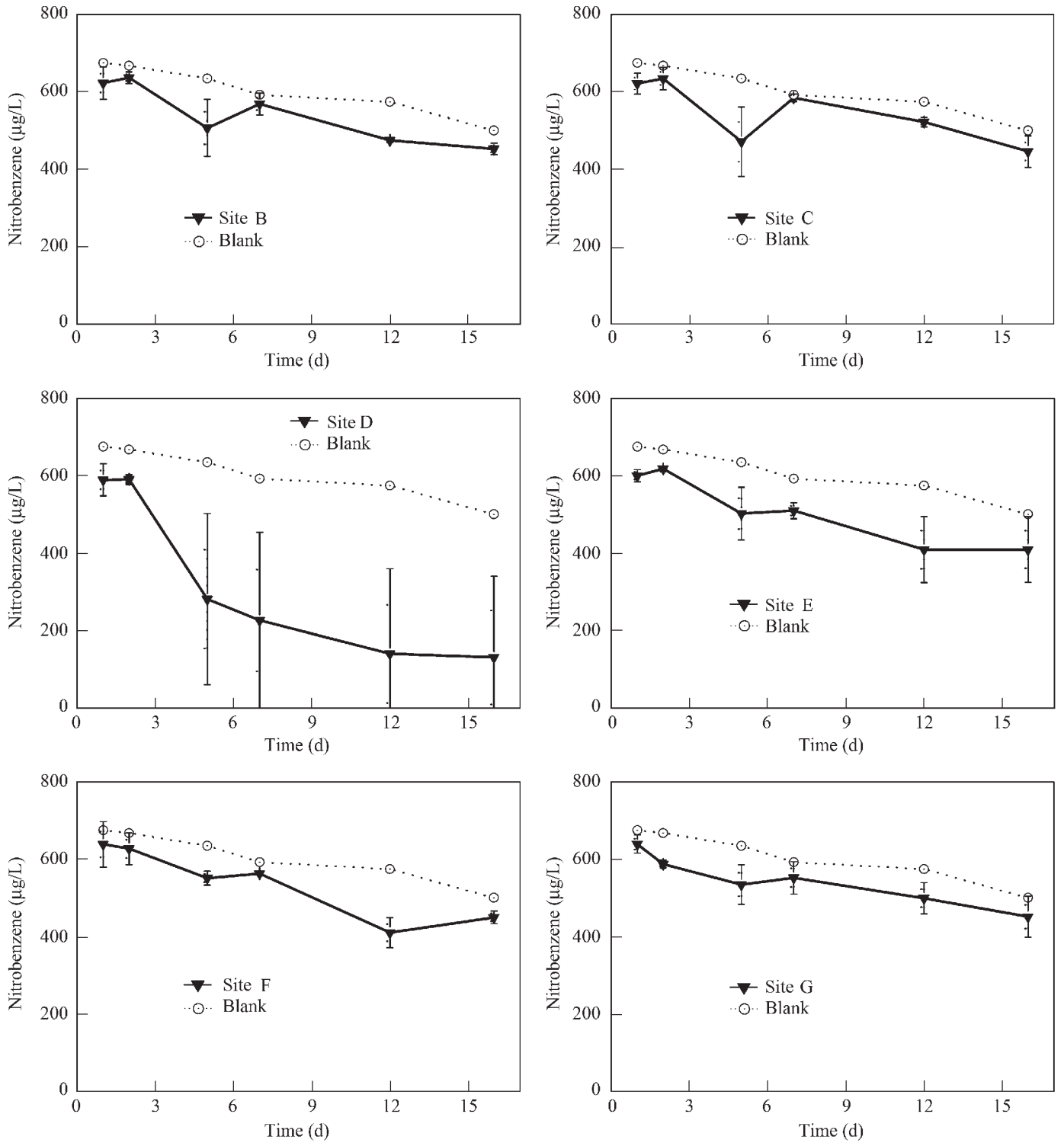

Fig. 5 NB biodegradation in river water at $10^{\circ} \mathrm{C}$.

\subsection{Verification of NB biodegradation}

To confirm that NB could be mineralized through biodegradation, a degradation test using high concentration of $\mathrm{NB}(15 \mathrm{mg} / \mathrm{L})$ and large liquor volume $(1.5 \mathrm{~L})$ was performed, and changes in DOC were monitored (Fig.7). The initial DOC varied between 7 and $9 \mathrm{mg} / \mathrm{L}$, which were lower than the calculated value of $10.2 \mathrm{mg} / \mathrm{L}(8.8$ $\mathrm{mg} / \mathrm{L} \mathrm{DOC} \mathrm{from} 15 \mathrm{mg} / \mathrm{L} \mathrm{NB}$ plus $1.4 \mathrm{mg} / \mathrm{L} \mathrm{DOC} \mathrm{from}$ mineral medium). The DOC decreased rapidly, and was below $4 \mathrm{mg} / \mathrm{L}$ on day 4 . On day 14, the DOC reached 1.6 $\mathrm{mg} / \mathrm{L}$, which was almost equivalent to the DOC value in the mineral medium. This indicated that NB was possibly mineralized by the microbes in the system.

To obtain more degradation proofs, another biodegradation system was set up using six $250 \mathrm{ml}$ flasks and possibly benzene ring cleavage functional genes, including $\mathrm{C} 23 \mathrm{O}$ and $C 12 O$ genes, which were monitored for over $12 \mathrm{~d}$ (Fig.8). As shown in Fig.8, the $C 23 O$ gene appeared on days 4 and 6 , and then disappeared from day 8 , whereas, the $C 12 O$ gene was undetected throughout the entire degradation period. Hence the changes of $\mathrm{C} 23 \mathrm{O}$ also support the theory that mineralization of NB might happen during biodegradation. To search for possible biodegradation intermediates, the samples were analyzed using GC/MS, but the intermediates were detected only in the day 4 sample (Fig.9). The possible reason was that the intermediates degraded quickly. As shown in Fig.9, only NB (retention time $11.0 \mathrm{~min}$ ), nitrosobenzene (retention time $7.45 \mathrm{~min}$ ), and aniline (retention time $8.92 \mathrm{~min}$ ) could be identified from the chromatogram. Therefore, it was clear that aniline and nitrosobenzene were the two main degradation intermediates. According to previous studies (Hugh, 2005), these two intermediary biodegradation products represented two different biodegradation pathways. NB could be easily converted to aniline, which could be further degraded with the catalysis of $C 23 O$ dioxygenase (Nishino and Spain, 1995). Nitrosobenzene was a product of NB deoxidization catalyzed by nitroreductase (Somerville et al., 1995), which was a different pathway for NB degra- 

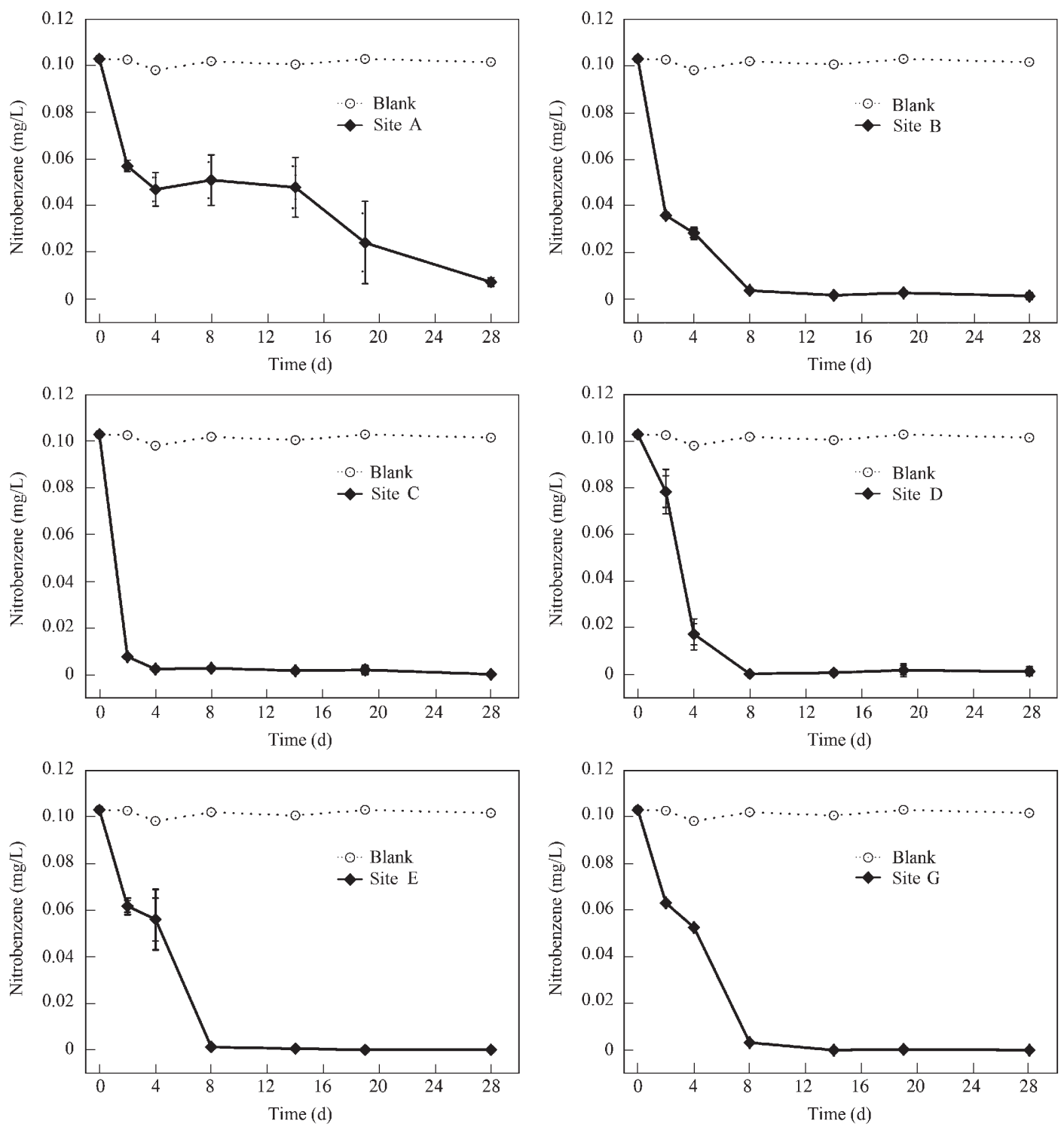

Fig. $6 \mathrm{NB}$ anaerobic biodegradation in sediments at $10^{\circ} \mathrm{C}$.

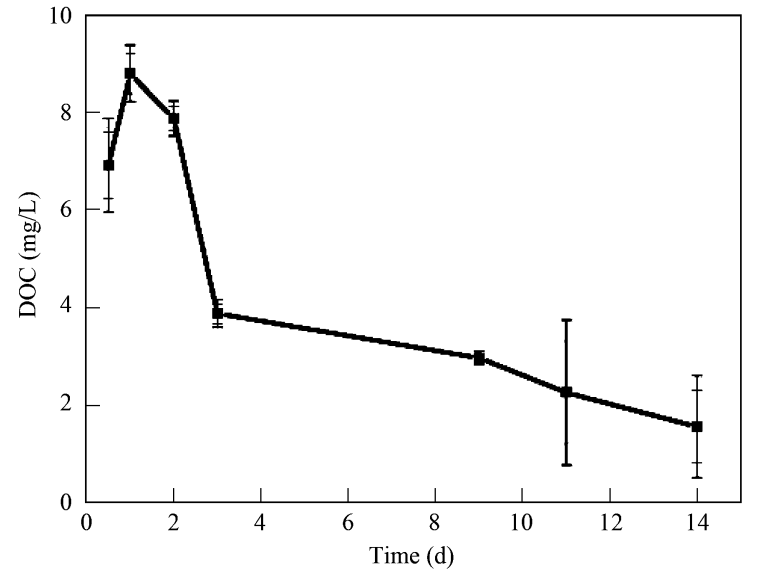

Fig. 7 DOC curve during biodegradation.

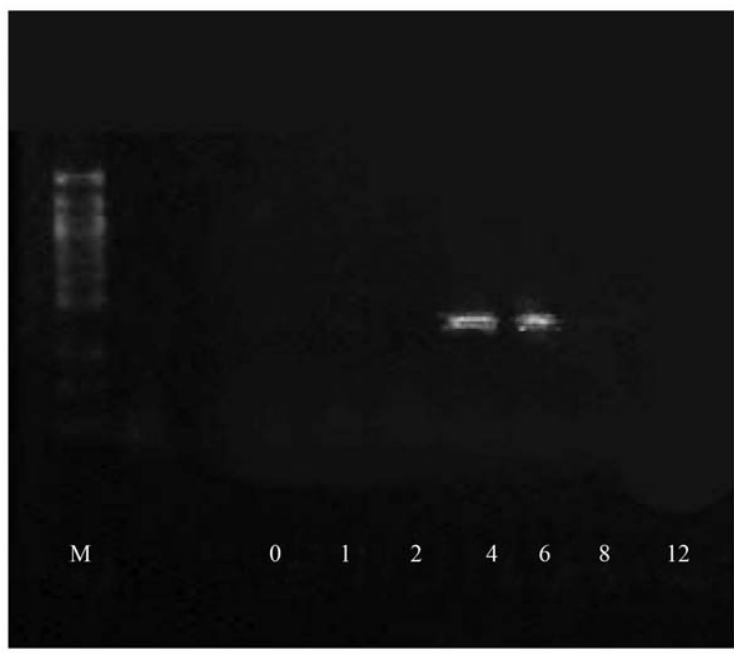

Fig. 8 Results for $\mathrm{C} 23 \mathrm{O}$ gene detection. 

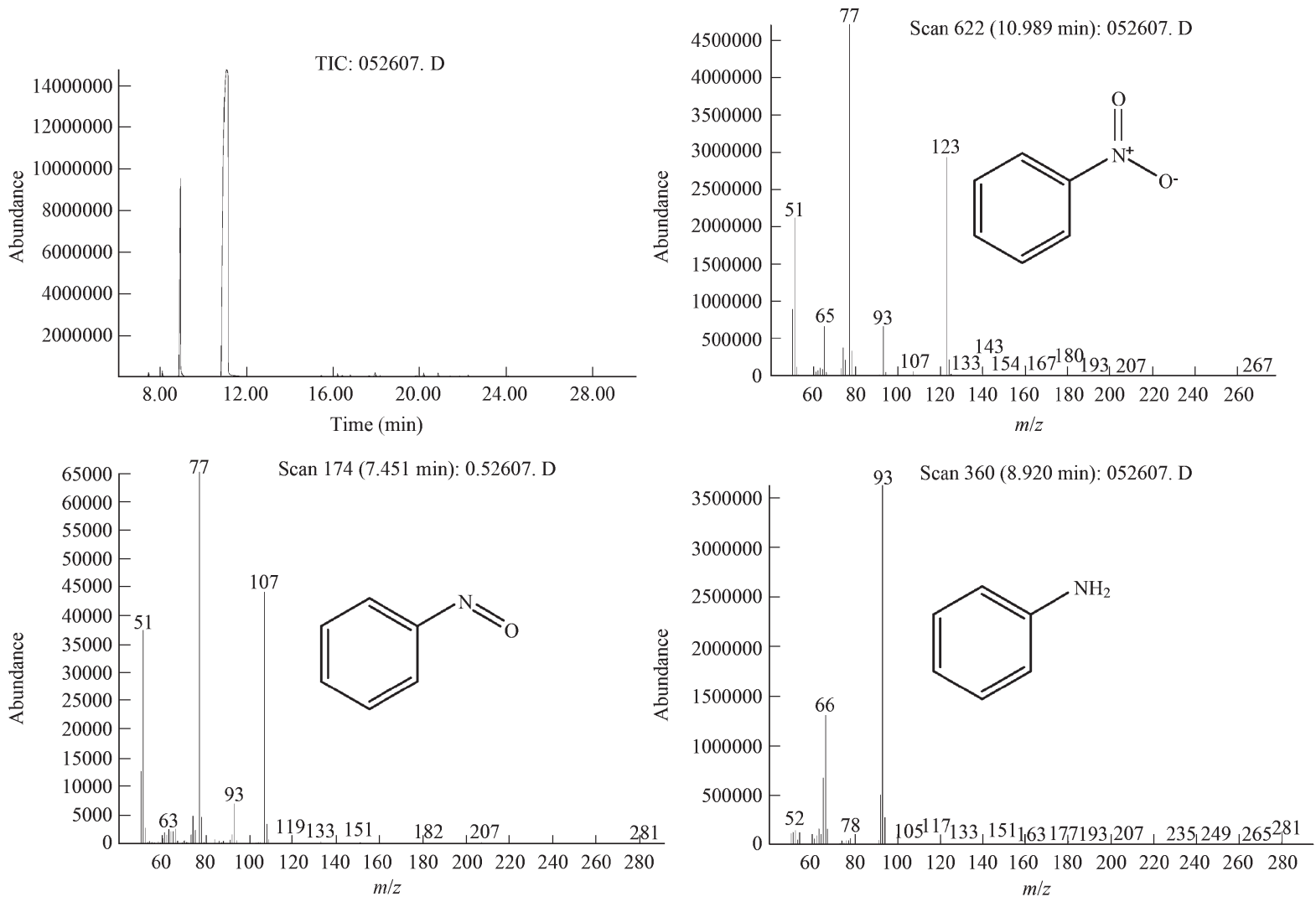

Fig. 9 GC/MS analysis results of sample taken on day 4.

dation. Therefore, the DOC, GC/MS, and PCR proofs support the theory that NB could be mineralized through biodegradation.

\subsection{Contribution of biodegradation to the loss of NB flux during the event}

According to other investigation results conducted at the same time (Liu et al., 2008), most of the NB released into the Songhua River existed in the river water rather than in the sediments and ice. Therefore, the behavior of NB in river water determined the fate of the NB released into the river. The State Environmental Protection Agency of China has reported that the polluted water strip left the Harbin section on November 25, 2005, and arrived at the Tongjiang section on December 17. It took approximately $22 \mathrm{~d}$ for the polluted strip to flow through the $711 \mathrm{~km}$ distance. The NB flux through the Harbin and Tongjiang sections was estimated to be approximately 46 and 25 $t$, respectively, suggesting that $21 \mathrm{t}$ of NB disappeared from the river water during the period. As described earlier, the NB in river water could not be removed at a temperature below $10^{\circ} \mathrm{C}$, through biodegradation. As the Songhua River was in a frozen state, it was reasonable to speculate that biodegradation of NB was not mainly responsible for the loss of NB flux. As demonstrated in the biodegradation experiments, NB could easily disappear from water through volatilization even at a temperature near zero. Thus, volatilization should be one of the main processes responsible for the loss of NB from river water. On the other hand, photolysis could also be responsible for the loss of NB (Wang et al., 2008).

\section{Conclusions}

Microbes in the Songhua River could biologically convert $\mathrm{NB}$ under both aerobic and anaerobic conditions at a favorable temperature, and microbial communities exposed to NB pollution showed higher NB degradation rates. NB could probably be mineralized through either the aniline or nitrosobenzene pathway. However, biodegradation of NB could not be mainly responsible for the loss of NB flux in the Songhua River during the pollution event, because NB could not be easily biodegraded at low temperatures. The high volatilization property of NB might be responsible for the loss of NB in the environment.

\section{Acknowledgements}

This work was supported by the Ministry of Science and Technology of China (No. 2006BA618A-01) and the National Natural Science Foundation of China (No. 50621804, 50525824).

\section{References}

Li D, Yang M, Li Z L, Qi R, He J Z, Liu H J, Change of bacterial communities in sediments along Songhua River in northeastern China after a nitrobenzene pollution event. FEMS Microbiology Ecology (in press).

Dias N, Poole C, 2002. Mechanistic study of the sorption properties of OASIS ${ }^{\circledR}$ HLB and its use in solid-phase extraction. 
Chromatographia, 56: 269-275.

EPA (United States Environmental Protection Agency), 1994. Nitroaromatics and Nitramines by High Performance Liquid Chromatography (HPLC). http://www.epa.gov/sw846/pdfs/8330.pdf.

Gurevich P, Oren A, Sarig S, Henis Y, 1993. Reduction of aromatic nitro-compounds in anaerobic ecosystems. Water Science and Technology, 27: 89-96.

He Z, Spain J C, 1999. Comparison of the downstream pathways for degradation of nitrobenzene by Pseudomonas pseudoalcaligenes JS45 (2-aminophenol pathway) and by Comamonas sp. JS765 (catechol pathway). Arch Microbiol, 171: 309-316.

Hugh M, 2005. Nitrobenzene pathway map. In: http://umbbd.ahc.umn.edu/nb/nb_map.html.

Liu R P, Liu H J, Wan D J, Qu J H, Yang M, 2008. Characterization of the Songhua River sediments and evaluation of their adsorption behavior for nitrobenzene. Journal of Environmental Sciences, 21(7): 796-802.

Liu Z, Yang H, Huang Z, Liu S J, 2002. Degradation of aniline by newly isolated, extremely aniline-tolerant Delftia sp. AN3. Appl Microbiol Biotechnol, 58: 679-682.

Majumder P S, Gupta S K, 2003. Hybrid reactor for priority pollutant nitrobenzene removal. Water Research, 37: 43314336.

Nishino S F, Spain J C, 1993. Degradation of nitrobenzene by a Pseudomonas pseudoalcaligenes. Appl Environ Microbiol, 59: 2520-2525.

Nishino S F, Spain J C, 1995. Oxidative pathway for the biodegradation of nitrobenzene by Comamonas sp. strain JS765. Appl Environ Microbiol, 61: 2308-2313.

OECD, 1992. Guideline of Testing of Chemicals 302B Zahn-Wellens/EMPA Test. www.oecd.org/detaoecd/17/18/ 1948225.pdf.

Razo-Flores E, Lettinga G, Field J A, 1999. Biotransformation and biodegradation of selected nitroaromatics under anaerobic conditions. Biotechnology Progress, 15: 358-365.

Schallenberg M, Kalff J, Rasmussen J B, 1989. Solutions to problems in enumerating sediment bacteria by direct counts. Appl Environ Microbiol, 55: 1214-1219.

Sei K, Asano K, Tateishi N, Mori K, Ike M, Fujita M, 1999. Design of PCR primers and gene probes for the general detection of bacterial populations capable of degrading aromatic compounds via catechol cleavage pathways. $J$ Biosci Bioeng, 88: 542-550.

Somerville C C, Nishino S F, Spain J C, 1995. Purification and characterization of nitrobenzene nitroreductase from Pseudomonas pseudoalcaligenes JS45. J Bacteriol, 177: 3837-3842.

Spain J C, 1995. Biodegradation of nitroaromatic compounds. Annual Review of Microbiology, 49: 523-555.

UNEP (The United Nations Environment Programme), 2005. The Songhua River Spill China, December 2005.

Wang A M, Hu C, Qu J H, Yang M, Liu H J, Ru J, 2008. Phototransformation of nitrobenzene in Songhua River: kinetics and photoproduct analysis. Journal of Environmental Sciences, 20(7): 787-795.

Ye J, Singh A, Ward O P, 2004. Biodegradation of nitroaromatics and other nitrogen-containing xenobiotics. World J Microb Biot, 20: 117-135.

Yuan X, Lang P, 1991. Simulation study on biodegradation kinetics of nitrobenzene in river water. Environmental Chemistry, 10: 24-30.

Zhao J S, Ward O P, 1999. Microbial degradation of nitrobenzene and mono-nitrophenol by bacteria enriched from municipal activated sludge. Can J Microbiol, 45: 427-432. 